\title{
ISOLATION AND FUNCTIONAL CHARACTERIZATION OF MONONUCLEAR PHAGOCYTES FROM HUMAN LEPROMATOUS LESIONS
}

\author{
Euzenir Nunes Sarno, Elizabeth Pereira Sampaio, André Luís Moreira \\ and Fátima de Barros Fonseca Alvarenga
}

\begin{abstract}
In the present study, inflammatory cells from human lepromatous lesions were isolated by enzymatic dissociation of tissue. They were maintained in culture up to five days and their morphologic, cythochemical and functional characteristics were described.
\end{abstract}

Key words: Macrophage. Enzymatic dissociation. Leprosy. Inflammatory cells.

The macrophage seems to have a major role in the pathogenesis of many chronic inflammatory diseases. Its different morphologic aspects seen in many lesions led to assume that these cells have different functions too. The isolation of macrophages from tissue lesions has been a difficult step hindering the researches about their biological functions at the site of injury.

In leprosy, the course of the disease is related to the macrophage capacity in destroying or not the bacillus within them. Epithelioid and giant cells are characteristic of the benign type of the disease. On the other hand, in the lepromatous type, mononuclear phagocytes carry many bacilli and are unable to kill them.

Isolation and culturing of macrophages from animals with experimental granulomatous disease have been done after enzymatic digestion of tissue ${ }^{1311}$. In this paper, these cells were isolated from human lepromatous lesions by using an enzyme mixture of collagenase, dispase and desoxiribonuclease and some of their functional properties were analyzed.

\section{MATERIAL AND METHODS}

A.J.S., male, 34 had a previous diagnosis of lepromatous leprosy, histoid form and no treatment. After permission, an excision was made in asseptic conditions by removing a piece of skin of about $3 \mathrm{~cm}$ in length. The biopsy specimen was minced until small fragments were obtained and worked as Dr. Gilla Kaplan recommendation (G Kaplan: personal communication, 1984). They were incubated at $37^{\circ} \mathrm{C}$ with enzyme mixture in RPMI medium without serum $(0.5 \mathrm{mg} / \mathrm{ml}$ collagenase, Millipore Corporation Freehold; $50 \mu \mathrm{g} / \mathrm{ml}$ DNAse, Sigma; $4 \mathrm{mg} / \mathrm{ml}$ Dispase, Sigma) and shaked in a magnetic stirrer for 20 minutes.

Departamento de Patologia Geral da Faculdade de Ciências Médicas, Universidade do Estado do Rio de Janeiro, UERJ, Brasil. Av. 28 de Setembro 87, Fundos 4: Andar, Vila Isabel, 20551 Rio de Janeiro, RJ.

Trabalho financiado em parte pelo $\mathrm{CNPq}$ - Processo no 40.0927/85 e pela Universidade Rockefeller.

Recebido para publicação publicação em 28/4/86.
The supernatant with the cells were then removed, kept on ice and $1.5 \mathrm{ml}$ of fetal bovine serum (FBS) was added ${ }^{7}$. The cells were washed twice in Hanks'solution and resuspended in $2 \mathrm{ml}$ RPMI (Sigma) supplemented with $2 \mathrm{mM}$ L-glutamine, $100 \mathrm{U} / \mathrm{ml}$ penicilin, $100 \mathrm{mg} / \mathrm{ml}$ streptomycin and $10 \%$ heat-inactivated FBS. The procedure was repeated many times until all the fragments were dissociated completely. After testing the cell viability by tripan blue exclusion ( 95 per cent), the cell concentration was adjusted to $10^{7}$ cells $/ \mathrm{ml}$. Then, $10^{6}$ cells were added to $13-\mathrm{mm}$ round glass coverslips and incubated at $37{ }^{\circ} \mathrm{C}$ in humid atmosphere with $5 \% \mathrm{CO}_{2}$ for 2 hours. At this time, adherent cells were removed, fresh medium was added an the coverslips maintained in culture for five days.

Morphologic characterization: Coverslips at 0 , 2, 20, 72 hours and five days culture were fixed, stained by Giemsa method and analyzed in light microscopy.

Cytochemistry characterization: This study was done through the analysis of non-specific esterase activity (ANAE) and acid phosphatase activity (ACP). The coverslips were fixed for 10 minutes at $4{ }^{\circ} \mathrm{C}$ in $0.25 \%$ glutaraldehyde and $1 \%$ sucrose in $0.1 \mathrm{M}$ sodium cacodylate buffer, $\mathrm{pH}$ 6.3. The cells were washed three times in the same buffer containing $2 \%$ sucrose at $4{ }^{\circ} \mathrm{C}$ and incubated with specific substrates as previously described ${ }^{5} 13$.

Functional assay: The phagocytic function of the macrophages was evaluated using Saccharomyces cerevisiae (SC). Fresh baker's yeast was processed by the method of Lachman and Hobart ${ }^{6}$. This procedure consists of autoclaving, reduction by mercaptoethanol, alkylation with iodoacetamide and extensive washing in PBS. To opsonize particles with complement components, the yeasts were incubated with fresh human serum for 30 minutes at $37{ }^{\circ} \mathrm{C}$ and washed twice in RPMI medium.

The adherent cells in culture were incubated with opsonized $\mathrm{SC}$ for 30 minutes at $37^{\circ} \mathrm{C}$. The yeast per cell concentration was determined in 10:1 $\left(5 \times 10^{6}\right.$ yeasts $\mathrm{ml}^{-1}$ approximately).After this period, the coverslips were washed in Hanks' and stained by Giemsa method. 
At least 200 cells in each coverslip were counted and the percent of cells containing two or more intracellular yeasts was determined.

All the experiments were done in duplicate. The converslips were counted by at least two persons and the mean values \pm standard deviation was estimated.

\section{RESULTS}

At least one coverslip from $0,2,24,72$ hours and five days culture were analyzed. The identification of mononuclear phagocytes was done on their morphologic and cytochemical characteristics. They showed diffuse cytoplasmic staining to ANAE and ACP (Fig. 1).

The glass coverslips with adherent cells at 0 and 2 hours had similar appearances. Epithelial cells predominate at 0 hour and decreased after 2 hours culture. The macrophage represented $48 \% \pm 1.7$ of the cell population, as evaluated by cytochemical assay, and displayed a variety of morphological aspects. Some of them looked like monocytoid macrophages. They were

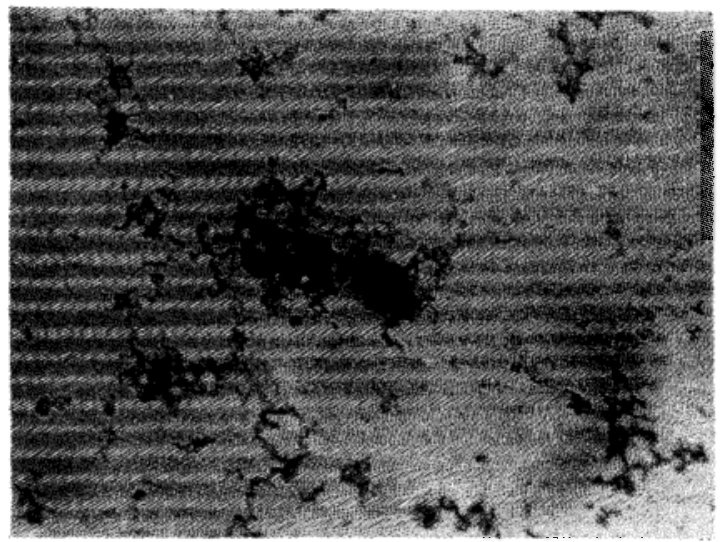

Fig. 1- Macrophage with diffuse cytoplasmic staining by ANAE. 2 hours culture. $400 \mathrm{X}$.

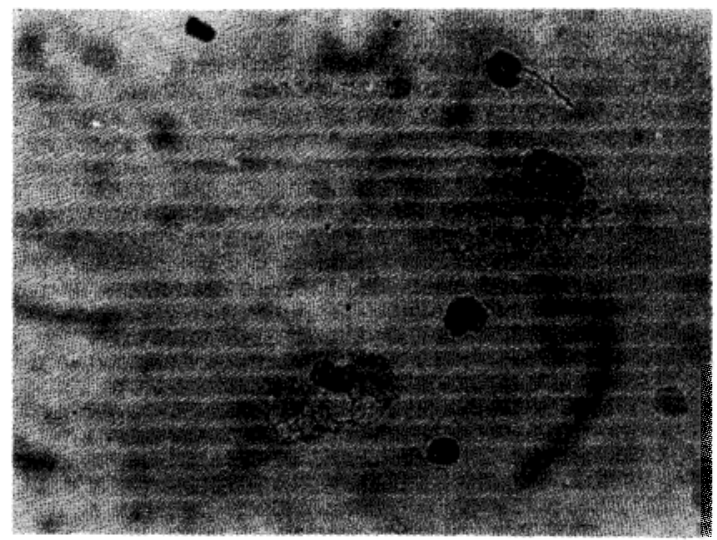

Fig. 2 - Vacuolized macrophages after 2 hours of adherence. In some vacuoles it could be seen granules suggesting acid fast bacilli. Giemsa staining. 400 . found with basophilic cytoplasm and eccentric nucleus. Others had elongated or irregular shape. About $2 \% \pm 0.8$ cells were large with vacuolized form cytoplasm and had central nucleus with very lax chromatin (Fig. 2). These cells were identified as Virchow -like cells and contained acid fast bacilli. T lymphocytes represented less than $1 \%$ of the total cells and were cytochemically characterized by small granules adjacent to cellular membrane ${ }^{4}$. Multinucleated cells with 2 or more nuclei were also seen in these preparations.

The cells identified in 24 hours culture were almost exclusively macrophages with many of them very well spread out. Bi and multinucleated cells (giant cells) were frequent (Fig. 3). At the $5^{\text {th }}$ day culture, there was very few viable cells. After 72 hours, the adherent cells decreased. The few cells remaining in the coverslips were large, flattened and vacuolized. Multinucleated cells were still present.

Phagocytic assay: cells containing two or more fungi represented $15.5 \% \pm 0.5$ of the total adherent cells present in the 24 hours culture. Some multinucleated cells also contained fungi within them (Fig. 4).

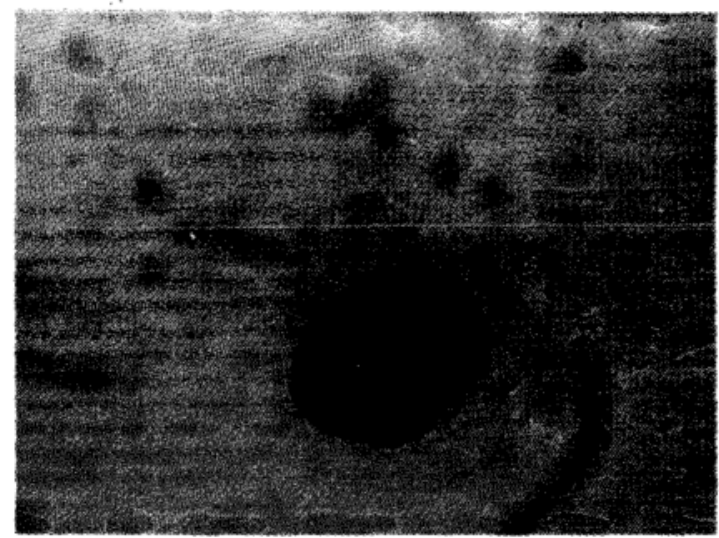

Fig. 3- Giant cell after 24 hours culture. Giemsa staining. $1000 x$.

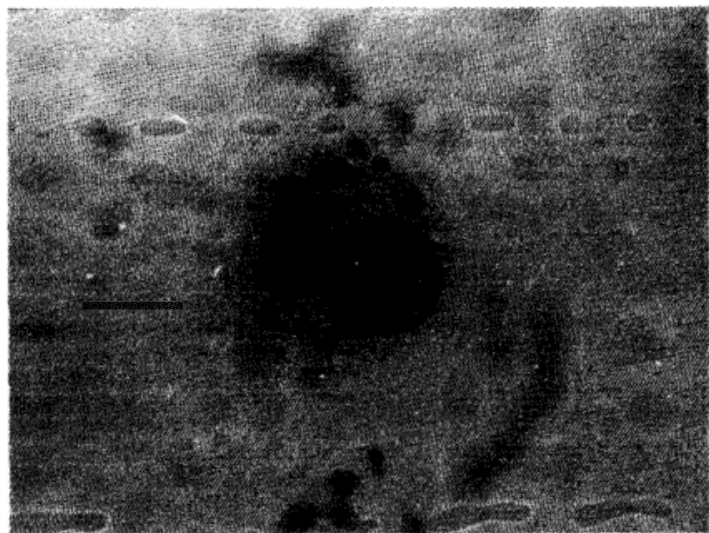

Fig. 4- Binucleated cell containing Saccharomyces cerevisiae. 24 hours culture. Giemsa staining. 1000X. 
Sarno EN, Sampaio EP, Moreira AL, Alvarenga FBF. Isolation and functional characterization of mononuclear phagocytes from human lepromatous lesions. Revista da Sociedade Brasileira de Medicina Tropical 20(4): 205-207, Out-Dez, 1987

\section{DISCUSSION}

The enzymatic dispersion has showed to be an efficient method for the isolation of mononuclear phagocytes from inflammatory lesions and neoplasms ${ }^{2} 8$. This method has also been used to cynetic studies of experimental granulomas 91012 . Nevertheless very few studies have been done in leprosy with the inflammatory lesion cells in culture. In the present study all the biopsy specimen was submitted to enzymatic digestion and this could explain the high number of epithelial cells obtained at the first hours. We believe we should peel of the epidermis in order to get more purified inflammatory cell population.

An interesting finding was the disagreement between the histologic and isolated population. In the histologic sections, no multinucleated cells were identified. However, as soon as the cells were isolated, multinucleated cells could already be seen. It is known that in the lepromatous leprosy, giant cells are not found in the tissue. This finding led us suppose that when the cells are removed from their micro-environment they could regain some of the blocked properties or acquire new ones.

The presence of Virchow like-cells among culturing cells allows one to admit that the capacity to adhere on glass remain unchanged, even if heavy charge of bacilli is present within the cell.

The different morphologic characteristics seen among isolated cells and the great number of them that looks like monocytes suggest that these cells may be in different stages of maturation. These data probably reflect some degree of cellular turnover. Other interesting finding was that at least 15 per cent of macrophages in culture maintained the capacity to phagocyte. $\mathrm{Ne}-$ vertheless if it is related or not with their bactericidal capacity must be proven further.

This research work provides a way for the efficient approach to macrophage behavior in lepromatous lesions which up to now had only been contempleted.

\section{RESUMO}

Células inflamatórias presentes em lesões Virchowianas humanas foram isoladas do tecido por um processo de digestão enzimática. Elas foram mantidas em cultura por cerca de 5 dias e suas características morfológicas citoquimicas efuncionais foram descritas.

Palavras-chaves: Macrófago. Dissociação enzimática. Hanseníase. Células inflamatórias.

\section{REFERENCES}

1. Amsden AF, Boros DL. Fc-receptor-bearing macrophages isolated from hypersensitivity and foreign-body granulomas. The American Journal of Pathology 96: 457473, 1979.

2. Bonney RJ. Obtaining mononuclear phagocytes from granulomas. In: Adams DO, Edelson PJ, Koren H (eds). Methods for studying mononuclear phagocytes, 1 st edition, Academic Press, Inc. New York, pp. 111-119, 1981.

3. Bonney RJ, Gery I, Lin TX, Meyenhofer MF, Acevedo W, Davies P. Mononuclear phagocytes from carrageenan-induced granulomas: Isolation cultivation and characterization. The Journal of Experimental Medicine 148: 261-275, 1978.

4. Bozdech MJ, Baiton DF. Identification of $\propto$-naphtyl butyrate esterase as a plasma membrane ectoenzyme of monocytes and as a discrete intracellular membranebounded organelle in lymphoc ytes. The Journal of Experimental Medicine 153: 182-195, 1981.

5. Chilosi M, Pizzolo G, Menestrina F, Iannucci AM, Bonetti F, Fiore-Donati L. Enzyme histochemistry on normal and pathologic paraffin-embedded lymphoid tissues. American Journal of Clinical Pathology 76: 729$736,1981$.

6. Lachman PJ, Hobart MJ. Complement Technology. In: Weir DM (ed). Handbook of Experimental Immunology Vol. 1 Immunochemistry, Blackwell, Oxford, 5A, 1-5A, 23, 1978.

7. Russel SW. Obtaining mononuclear phagocytes from disaggregated neoplasms. In: Adams DO, Edelson PJ, Koren $\mathrm{H}$ (eds). Methods for studying mononuclear phagocytes, 1st edition, Academic Press, Inc. New York, pp. 103-109, 1981.

8. Russel SW, Doe WF, Hoskins RG, Cochrane CG. Inflammatory cells in solid neoplasms. I. Tumor disaggregation and identification of constituent inflammatory cells. International Journal of Cancer 18: 322-330, 1976.

9. Stadecker MJ, Wiler DJ, Wright JA. Ia antigen expression and antigen-presenting function by macrophages isolated from hypersensitivity granulomas. The Journal of Immunology 128: 2739-2744, 1982.

10. Stadecker MJ, Wright JA. Distribution and kinetics of mononuclear phagocytes in granulomas elicited by eggs of Schistosoma mansoni. The American Journal of Pathology 116: 245-254, 1984

11. Williams GT. Isolated epithelioid cells from disaggregated BCG granulomas - An ultrastructural study. The Journal of Pathology 136: 1-13, 1982.

12. Williams GT. Isolated epithelioid cells from disaggregated BCG granulomas - Some functional studies. The Journal of Pathology 136: 15-25, 1982.

13. Yam LT, Li CY, Crossby NH. Cytochemical identification of monocytes and granulocytes. American Journal of Clinical Pathology 55: 283-290, 1971. 